ISSN: 2302-8556

E-Jurnal Akuntansi Universitas Udayana

Vol.24.3.September (2018):1799-1827

DOI: https://doi.org/10.24843/EJA.2018.v24.i03.p06

\title{
Opini Auditor dan Solvabilitas Sebagai Pemoderasi Pengaruh Profitabilitas terhadap Audit Delay
}

\author{
I Gede Ari Dewanto ${ }^{1}$ \\ A.A Ngurah Bagus Dwirandra² \\ ${ }^{1}$ Fakultas Ekonomi dan Bisnis Universitas Udayana, Bali, Indonesia
email: gdaridewanto@ gmail.com/ +6281916685881
${ }^{2}$ Fakultas Ekonomi dan Bisnis Universitas Udayana, Bali, Indonesia
}

\begin{abstract}
ABSTRAK
Audit delay merupakan waktu yang dibutuhkan oleh auditor untuk menghasilkan laporan audit atas kinerja laporan keuangan suatu perusahaan. Tujuan penelitian ini adalah untuk mendapatkan bukti empiris tentang opini auditor dan solvabilitas sebagai pemoderasi pengaruh profitabilitas terhadap audit delay. Penelitian ini dilakukan di perusahaan manufaktur yang terdaftar di Bursa Efek Indonesia (BEI) dengan periode waktu penelitian pada tahun 2013-2015. Metode penentuan sampel dalam penelitian ini menggunakan metode purposive sampling dengan sampel sebanyak 165 perusahaan manufaktur selama periode 2013-2015 yang sudah memenuhi kriteria penentuan sampel. Teknik analisis data yang diterapkan dalam penelitian ini adalah uji nilai selisih mutlak. Hasil penelitian menunjukkan bahwa Profitabilitas berpengaruh negatif signifikan terhadap audit delay. Opini Auditor memperkuat pengaruh negatif profitabilitas terhadap audit delay. Solvabilitas memperlemah pengaruh negatif profitabilitas terhadap audit delay.
\end{abstract}

Kata Kunci: Audit Delay, Profitabilitas, Opini Auditor, Solvabilitas.

\begin{abstract}
Audit delay is the time required by the auditor to generate audit reports on the performance of a company's financial statements. The purpose of this study is to obtain empirical evidence about auditor opinion and solvency as a moderator of profitability effect on audit delay. This research was conducted at a manufacturing company listed on the Indonesia Stock Exchange (IDX) with a period of research in 2013-2015. The method of determining the sample in this study using purposive sampling method with a sample of 165 manufacturing companies during the period 2013-2015 that already meet the criteria for determining the sample. Data analysis technique applied in this research is test of absolute difference value. The results showed that Profitability had a significant negative effect on audit delay. Auditor opinion strengthens the negative effect of profitability on audit delay. Solvency weakens the negative effect of profitability on audit delay.
\end{abstract}

Keywords: Audit Delay, Profitability, Auditor Opinion, Solvency. 


\section{PENDAHULUAN}

Laporan keuangan adalah suatu bentuk instrumen yang wajib dibuat oleh suatu perusahaan demi mendukung keberlangsungan perusahaan, terutama bagi perusahaan yang telah go public dimana laporan keungan menjadi sumber informasi yang penting bagi investor yang akan menanamkan modal di pasar modal. Laporan keuangan yang disusun harus sesuai dengan Standar Akuntansi Keuangan (SAK) yang berlaku dan telah diaudit oleh akuntan publik atau auditor independen yang telah terdaftar di Badan Pengawas Pasar Modal (Bapepam).

Berdasarkan ketentuan dari Bapepam-LK seluruh perusahaan yang terdaftar dalam pasar modal diwajibkan menyampaikan laporan keuangan secara berkala kepada pihak publik. Peraturan ini menyatakan bahwa laporan keuangan tahunan wajib disertai laporan akuntan dalam rangka audit atas laporan keuangan, dan wajib disampaikan kepada Bapepam-LK serta diumumkan kepada masyarakat paling lambat akhir bulan ketiga setelah tanggal laporan keuangan tahunan perusahaan. Bapepam-LK mengharuskan perusahaan publik melaporakan laporan keuangan yang telah diaudit dalam 60 sampai 90 hari setelah penutupan periode pembukuan (Arens et al, 2011: 152).

Laporan keuangan memiliki peranan yang sangat penting dalam proses pengukuran dan penilaian kinerja suatu perusahaan. Informasi yang terdapat dalam laporan keuangan perusahaan dapat bermanfaat, apabila disajikan secara akurat dan tepat waktu pada saat yang dibutuhkan oleh para pengguna laporan keuangan, seperti kreditor, investor, pemerintah, masyarakat dan pihak-pihak lain sebagai dasar pengambilan suatu keputusan. Maka dari itu informasi yang 
terkandung dalam laporan keuangan harus disajikan dan dilaporakan secara andal, relevan, dapat diperbandingkan, dan dapat dipahami.

Konsep pengungkapan yang umumnya diusulkan adalah pengungkapan yang cukup (adequate), wajar (fair), dan lengkap (full). Dari pengungkapan tersebut, yang paling umum digunakan dari ketiga konsep di atas adalah pengungkapan yang cukup, mencakup pengungkapan minimal yang harus dilakukan agar laporan keuangan tidak menyesatkan. Sementara itu, wajar menunjukkan tujuan etis agar dapat memberikan perlakuan yang sama dan bersifat umum bagi semua pemakai laporan keuangan. Pengungkapan yang lengkap mensyaratkan perlunya penyajian semua informasi yang relevan. Mengacu pada konsep relevansi dan reliabilitas, penyajian laporan keuangan menuntut pemenuhan karakteristik kualitatif dari informasi yang disajikan.

Beberapa catatan mengungkapkan masih terdapat beberapa emiten yang terlambat dalam penyampaian laporan keuangan. Berdasarkan catatan bursa efek Indonesia hingga 31 Maret 2015, menyebutkan 52 perusahaan belum menyampaikan laporan keuangan tepat waktu terkait penyampaian laporan keuangan auditan yang berakhir 31 Desember 2014. Keterangan mengenai perusahaan tersebut 13 perusahaan tercatat menyampaikan informasi mengenai keterlambatan penyampaian laporan keuangan sedangkan 39 perusahaan tidak menyampaikan informasi meengenai keterlambatannya. Sebelumnya ditahun 2013, terdapat tiga emiten yang terkena denda atas keterlambatan penyampaian laporan keuangan. Sanksi denda dan peringatan tertulis diberikan karena perusahaan tidak menyampaikan laporan keuangan (Prasongkoputra, 2013). 
I Gede Ari Dewanto dan A.A Ngurah Bagus Dwirandra. Opini...

Karakteristik relevan berarti laporan tersebut mampu mendeskripsikan kondisi keuangan perusahaan secara tepat waktu. Suwarjono 2002, dalam penelitian Wirakusuma, 2004 menyebutkan bahwa ketepatwaktuan informasi bermakna informasi tersedia sebelum kehilangan kemampuan mempengaruhi keputusan maupun untuk membuat perbedaan dalam suatu keputusan. Termasuk pula dalam SAK (2004), bahwa penundaan yang tidak semestinya dalam pelaporan keuangan akan berakibat pada hilangnya relevansi laporan keuangan.

Ketepatan waktu perusahaan dalam mempublikasikan laporan keuangan kepada masyarakat umum dan kepada Bapepam juga tergantung dari ketepatan waktu auditor dalam menyelesaikan pekerjaan auditnya (Mantik dan Sujana 2012). Laporan keuangan dapat dikatakan bermanfaat, selain harus tepat waktu pelaporannya kepada publik, laporan keuangan juga harus diaudit oleh seorang akuntan publik (Owusu-Ansah, 2000). Kartika (2011) menyebutkan tujuan audit secara umum atas laporan keuangan oleh auditor adalah untuk menyatakan pendapat atas kewajaran dalam semua hal yang material, posisi keuangan hasil usaha dan arus kas yang sesuai dengan prinsip akuntansi yang berlaku umum di Indonesia. Ketepatwaktuan publikasi dapat memberikan sinyal kepada publik berkaitan dengan kemampuan perusahaan dan informasi akuntansi yang kredibel (Dania dan Sujana, 2017).

Auditor merupakan pihak ketiga yang dipilih oleh manajer dan pemegang saham untuk memeriksa laporan keuangan perusahaan, maka dari itu hal ini sangat terkait dengan adanya teori keagenan. Dalam penelitian Darmayanti (2014) prinsip utama teori keagenan menyatakan adanya hubungan kerja antara pihak 
yang memberi wewenang yaitu investor dengan pihak yang menerima wewenang yaitu manajer. Hubungan agensi muncul ketika satu orang atau lebih memperkerjakan orang lain untuk memberikan suatu jasa dan kemudian mendelegasikan wewenang pengambilan keputusan kepada agen tersebut.

Teori keagenan menggambarkan konflik antara pemilik dan manajer dalam beberapa hal, dan konflik tersebut secara eksplisit maupun implisit tercermin pada laporan keuangan (Astika, 2010: 64). Teori keagenan juga dipergunakan untuk menjelaskan kebutuhan akan audit. Cara pemilik memonitor kontrak dengan manajer dilakukan melalui pelaporan secara rutin. Dengan adanya konflik dari hubungan keagenan tersebut, maka dibutuhkan pihak ketiga yang mampu menengahi konflik tersebut. Pihak ketiga yang dimaksud yaitu auditor independen. Auditor berfungsi sebagai pelaksana verifikasi independen atas laporan keuangan yang disajikan manajer kepada pemilik. Selain itu dalam penelitian ini auditor memiliki dampak yang sangat penting, karena auditor independen ditunjuk untuk memberikan opini atas audit laporan keuangan perusahaan.

Teori pendukung dalam penelitian ini adalah teori sinyal. Menurut Jama'an (2008) teori sinyal menjelaskan tentang bagaimana seharusnya sebuah perusahaan memberikan sinyal kepada pengguna laporan keuangan. Subalno (2009) menjelaskan sangat penting bagi perusahaan untuk memberikan informasi mengenai setiap akun yang terdapat pada laporan keuangan sebagai sinyal apa yang sedang terjadi dalam perusahaan untuk diinformasikan kepada investor maupun calon investor. Pemberian sinyal berupa informasi oleh manajer 
dilakukan untuk mengurangi adanya asimetri informasi. Meminimalkan asimetri informasi perlu dilakukan agar perusahaan yang sudah go public dapat menginformasikan keadaan perusahaan secara transparan kepada para investor dan pengguna informasi laporan keuangan lainnya.

Standar auditing yang berlaku umum atas laporan keuangan auditan memiliki sejumlah keterbatasan bawaan atau keterbatasan melekat, salah satunya bahwa auditor bekerja dalam suatu batasan ekonomi yang wajar (Halim, 2008: 91). Ada dua batasan ekonomi penting yang dimaksud, antara lain biaya yang memadai dan jumlah waktu yang memadai. Pemenuhan standar oleh auditor tidak hanya berdampak pada lamanya penyelesaian laporan audit, tetapi juga berdampak pada peningkatan kualitas hasil audit (Purnamasari, 2012). Atas dasar standar tersebut dapat menyebabkan lamanya waktu penyelesaian audit yang dilakukan oleh auditor. Lamanya waktu penyelesaian audit atas laporan keuangan ini yang dinamakan dengan audit delay.

Audit delay merupakan senjang waktu audit, yaitu waktu yang dibutuhkan oleh auditor untuk menghasilkan laporan audit atas kinerja laporan keuangan suatu perusahaan (Puspitasari, 2012). Hajiha dan Rafiee (2011), mengukur audit delay dilihat dari jumlah hari antara akhir tahun fiskal laporan keuangan hingga diterbitkannya laporan audit independen. Menurut Parameswari (2012), audit delay yang terjadi di Indonesia akan berdampak negatif bagi kelangsungan perusahaan karena lamanya waktu penyelesaian proses audit akan mempengaruhi ketepatan waktu dalam publikasi informasi laporan keuangan auditan. Oleh 
karena itu semakin singkat audit delay, maka akan semakin relevan laporan keuangan yang dipublikasikan oleh perusahaan.

Laporan audit akan semakin dipercaya jika laporan auditan diselesaikan secara tepat waktu. Tetapi masih banyak perusahaan yang terlambat dalam pelaporan laporan auditan untuk dipublikasikan, sehingga tingkat kepercayaan investor akan berkurang terdahap laporan keuangan perusahaan tersebut. Semakin panjang audit delay maka tingkat kepercayaan dan kandungan laporan keuangan akan semakin diragukan oleh investor dan juga sebaliknya jika audit delay semakin pendek tingkat kepercayaan investor akan lebih meningkat.

Terdapat banyak faktor yang dapat mempengaruhi audit delay itu sendiri baik faktor internal maupun faktor eksternal (Aryaningsih, 2013). Dalam penelitian ini faktor yang diduga mempengaruhi audit delay diantaranya profitabilitas, opini auditor dan solvabilitas. Penelitian tentang audit delay juga sudah banyak dilakukan di Indonesia, namun pada penelitian ini yang berbeda dari penelitian sebelumnya, peneliti menambahkan variabel moderasi. Tujuan penambahan variabel moderasi dengan menggunakan opini auditor dan solvabilitas yang dilihat dari opini yang diberikan oleh auditor dan rasio solvabilitas yang diukur dengan debt to equity rasio (DER) memoderasi pengaruh profitabilitas terhadap audit delay. Variabel profitabilitas dipilih kembali oleh peneliti dikarenakan peneliti ingin meneliti kembali variabel tersebut yang dilihat dari penelitian sebelumnya yang masih berbeda-beda dan belum konsisten.

Lokasi penelitian ini dilakukan pada peusahaan manufaktur yang terdaftar di Bursa Efek Indonesia. Perusahaan manufaktur dipilih oleh peneliti karena 
memiliki kompleksitas dalam pelaporan keuangan yang akan memengaruhi terjadinya audit delay. Supaya mendapatkan data dengan dimensi waktu yang baru dari penelitian sebelumnya, peneliti menggunakan data terbaru pada periode tahun 2013-2015. Dengan perbedaan yang dilakukan pada penelitian ini diharapkan dapat memberikan hasil yang lebih signifikan dari penelitian sebelumnya dan topik yang diajukan menjadi menarik untuk diteliti kembali. Berdasarkan uraian latar belakang permasalahan di atas, maka permasalahan dalam penelitian ini dapat dirumuskan yaitu apakah opini auditor dan solvabilitas mampu memoderasi pengaruh profitabilitas terhadap audit delay.

Penelitian Lestari (2010) pada 100 perusahaan di Indonesia menemukan rata-rata audit delay yaitu 71,80 hari. Audit delay inilah yang dapat mempengaruhi ketepatan informasi yang dipublikasikan, sehingga akan berpengaruh tingkat ketidakpastian keputusan yang berdasarkan informasi yang dipublikasikan (Aston et al., 1987). Penelitian Jaggi dan Tsui (1999) menemukan bahwa audit delay cenderung semakin lama pada perusahaan yang mempunyai tingkat return on asset (ROA) yang rendah dan perusahaan yang mempunyai resiko bisnis yang tinggi.

Profitabilitas menunjukan keberhasilan perusahaan dalam memperoleh keuntungan atau laba. Perusahaan yang mempunyai profitabilitas yang tinggi akan berharap auditor melaksanakan audit dengan tepat waktu, sehingga laporan keunagan dapat diumumkan kepada publik secepatnya (Sagita, 2011). Tujuannya adalah untuk menunjukan kepada investor bahwa perusahaan memiliki kinerja yang baik serta selalu melaporkan kondisi terkini perusahaan sesuai dengan 
peraturan yang diberlakukan oleh otpritas jasa keuangan selaku otoritas pasar modal (Rahmayanti, 2016). Dengan demikian, audit delay akan lebih singkat pada perusahaan yang mempunyai profitabilitas tinggi (Iskandar dan Trisnawati, 2010).

Penelitian ini mengukur profitabilitas dengan menggunakan return on asset (ROA) karena dapat menilai apakah perusahaan telah efisien dalah menggunakan aktivanya pada kegiatan operasionalnya menghasilkan keuntungan. Return on asset (ROA) adalah perbandingan antara jumlah laba yang dihasilkan terhadap aset yang digunakan, sehingga menunjukan sejumlah perusahaan mampu menghasilkan laba dari sumber daya (asset) yang dimiliki. Dengan demikian kemungkinan profitabilitas yang diukur dengan ROA dapat mempengaruhi audit delay (Setiawan, 2013).

Perusahaan yang mengalami rugi (profitabilitas rendah) menunjukan kegagalan keuangan perusahaan maupun kemungkinan terjadinya kecurangan manajemen mengenai informasi tentang laba perusahaan (Carslaw dan Kaplan, 1991), sehingga auditor akan cendrung lebih berhati-hati selama proses audit untuk mendeteksi terjadinya hal tersebut. Akibatnya, audit delay akan lebih lama pada perusahaan yang mengalami rugi. Hasil penelitian ini konsisten dengan penelitian yang dilakukan Lestari (2010), Ikbal dkk (2012), Aryani (2014) dan Miradhi dan Juliarsa (2016) dimana hasil dari penelitian tersebut profitabilitas berpengaruh negatif pada audit delay.

Berdasarkan pengembangan kerangka pemikiran teoritis dan hasil-hasil riset empiris maka dapat dikembangkan hipotesis penelitian sebagai berikut : $\mathrm{H}_{1}$ : Profitabilitas berpengaruh negatif pada audit delay. 
I Gede Ari Dewanto dan A.A Ngurah Bagus Dwirandra. Opini...

Tingkat profitabilitas perusahaan menunjukan kinerja suatu perusahaan tersebut. Maka tingkat profitabilitas yang rendah akan berpengaruh terhadap audit delay. Hal tersebut berkaitan dengan akibat yang dapat ditimbulkan pasar terhadap pengumuman rugi oleh perusahaan. Owusu-Ansah (2000), dalam Lestari (2010), perusahaan yang memiliki hasil gemilang (good news) akan melaporkan lebih tepat waktu dibandingkan dengan perusahaan yang mengalami kerugian (bad news). Hal yang senada juga dikemukakan dalam penelitian Annisa (2004), perusahaan dengan hasil yang baik akan melaporkan lebih cepat dari perusahaan yang gagal operasi atau merugi. Tidak sejalan dengan hasil penelitian Ashton (1987) menyatakan bahwa profitabilitas tidak berpengaruh secara signifikan terhadap audit delay.

Tujuan akhir dari audit laporan keuangan perusahaan yaitu opini yang diberikan oleh auditor terhadap perusahaan. Opini dalam laporan keuangan menjadi tanggung jawab auditor untuk menilai dan mengumpulkan bukti yang mendasari atas laporan keuangan dan mengumpulkan bukti yang mendasari atas laporan keuangan perusahaan. Destina (2010), dan Ferdianto (2011), menyatakan bahwa opini auditor berpengaruh secara signifikan terhadap audit delay. Pernyataan tersebut didukung oleh penelitian Karang (2015) beserta Carslaw dan Kaplan (1991), menyatakan bahwa perusahaan yang tidak mendapat opini audit standar unqualified opinion diperkirakan mengalami audit delay yang lebih panjang alasannya perusahaan yang menerima opini tersebut memandang sebagai bad news dan akan memperlambat proses audit. Hasil yang berbeda dari Kartika (2011), dan Prameswari (2012), menyatakan opini auditor tidak berpengaruh 
terhadap audit delay. Dari uraian diatas maka dapat disimpulkan bahwa perusahaan yang mendapatkan opini audit dengan pendapat wajar tanpa pengecualian di tahun sebelumnya maka audit delay akan semakin pendek sedangkan bagi perusahaan yang mendapatkan opini selain pendapat wajar tanpa pengecualian di tahun sebelumnya akan audit delay akan lebih panjang karena auditor lebih berhati-hati dalam melakukan audit.

Berdasarkan pengembangan kerangka pemikiran teoritis dan hasil-hasil riset empiris maka dapat dikembangkan hipotesis penelitian sebagai berikut :

$\mathrm{H}_{2}$ : Opini auditor memoderasi pengaruh negatif profitabilitas terhadap audit delay.

Profitabilitas adalah kemampuan perusahaan dalam memperoleh keuntungan. Profitabilitas biasanya dilihat dari laporan laba rugi perusahaan, karena dalam laporan laba rugi perusahaan dapat menunjukkan kinerja suatu perusahaan. Estrini dan Laksito (2013), Setiawan (2013). Rachmawati (2008), yang menjelaskan bahwa perusahaan yang memiliki tingkat profitabilitas yang lebih tinggi membutuhkan waktu dalam pengauditan laporan keuangan lebih cepat dikarenakan keharusan untuk menyampaikan kabar baik secepatnya kepada publik. Informasi laba yang dihasilkan perusahaan dijadikan sebagai salah satu dasar pengambilan keputusan untuk membeli atau menjual kepemilikan yang dimiliki oleh investor (Kartika, 2011). Perusahaan yang memiliki tingkat profitabilitas yang rendah kemungkinan akan meminta auditornya untuk memperpanjang waktu audit lebih lama dari biasanya (Carslaw dan Kaplan, 1991).

Ketika proporsi hutang terhadap jumlah ekuitas meningkat, maka mengaudit akun hutang akan memakan waktu relatif lebih lama karena harus 
mencari sumber penyebab dari tingginya proporsi hutang yang dimiliki oleh perusahaan serta membutuhkan banyak waktu untuk menkonfirmasi pihak-pihak (debtholder) yang berkaitan dengan perusahaan (Aryaningsih, 2014). Saat setelah laporan keuangan disajikan dan perusahaan tersebut mempunyai solvabilitas tinggi hal ini merupakan bad news dalam laporan keuangan. Sehingga pihak manajemen akan berusaha untuk melakukan manajemen laba untuk menutupi hal tersebut. Oleh karena itu, pihak auditor akan lebih berhati-hati untuk mengaudit perusahaan dan akan memakan waktu lebih lama untuk mengaudit akun hutang sehingga audit delay akan lebih panjang.

Berdasarkan pengembangan kerangka pemikiran teoritis dan hasil-hasil riset empiris maka dapat dikembangkan hipotesis penelitian sebagai berikut :

$\mathrm{H}_{3}$ : Solvabilitas memoderasi pengaruh negatif profitabilitas terhadap audit delay

\section{METODE PENELITIAN}

Pendekatan yang digunakan dalam penelitian ini adalah kuantitatif dengan metode penelitian asiosiatif. Penelitian asosiatif adalah penelitian yang bertujuan untuk mengetahui hubungan antara dua variabel atau lebih yang mempunyai hibungan sebab akibat. Selain itu pula, terdapat variabel moderasi yang mempengaruhi (memperkuat atau memperlemah) hubungan antar variabel independen dengan dependen. Berikut merupakan gambar desain dari penelitian ini. 


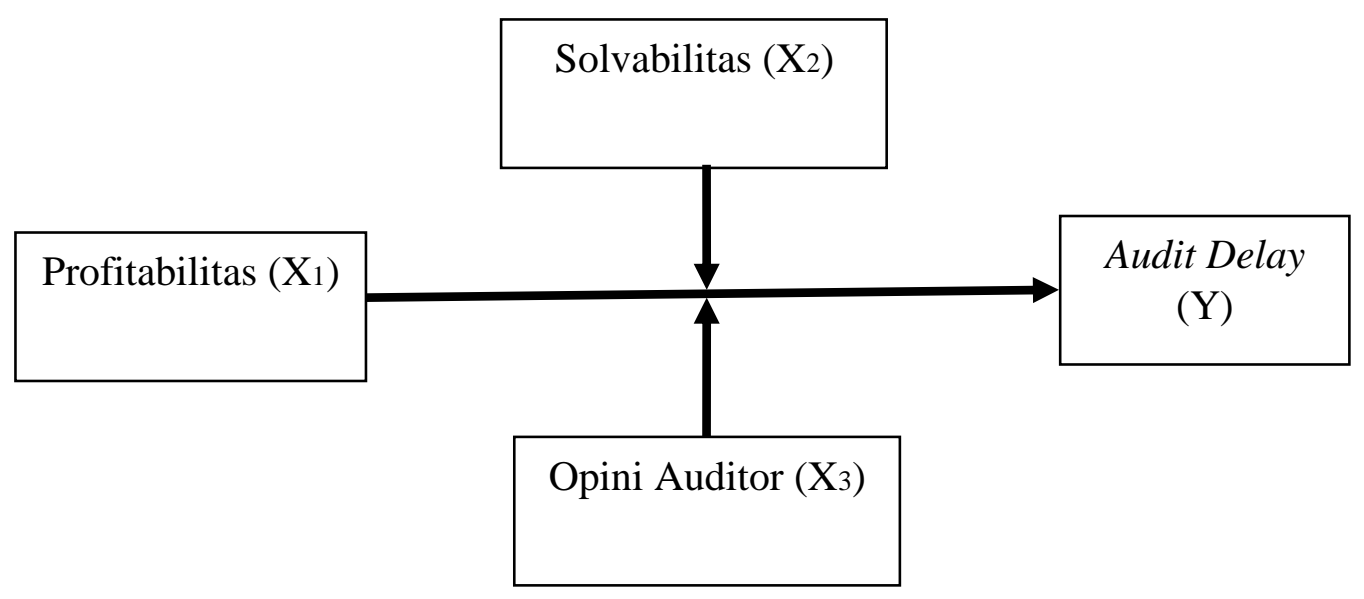

\section{Gambar 1. Desain Penelitian}

Lokasi dalam penelitian ini adalah seluruh sektor perusahaan manufaktur yang terdaftar di Bursa Efek Indonesia tahun 2013-2015, yang diakses melalui situs www.idx.co.id. Sedangkan objek penelitiannya adalah audit delay yang dipengaruhi profitabilitas dengan opini auditor dan solvabilitas sebagai pemoderasi. Opini auditor dan solvabilitas dalam penelitian ini berfungsi dalam memoderasi pengaruh antara variabel dependen dengan variabel independen.

Variabel dependen dalam penelitian ini adalah audit delay (Y) yaitu lamanya waktu penyelesaian audit laporan keuangan tahunan, diukur berdasarkan lamanya hari yang dibutuhkan untuk memperoleh laporan audit independen atas audit laporan keungan tahunan. Sejak tanggal tahun tutup buku perusahaan yaitu 31 Desember sampai tanggal yang tertera pada laporan audit independen (Anindyanari, 2017).

Rasio profitabilitas mengukur seberapa besar kemampuan perusahaan dalam menghasilakan keuntungan (Mulyadi, 2009). Dalam penelitian ini menggunakan 
return on asset (ROA) sebagai alat ukur untuk mengukur tingkat profitabilitas dengan sedikit memodifikasinya, dimana total aset dalam penelitian ini dirataratakan dengan nilai rata-rata didapatkan dari nilai awal tahun yang didapat dari total aset tahun sebelumnya ditambahkan tahun sekarang dibagi dua. Return on asset (ROA) dapat dihitung sebagai berikut:

$$
\text { Return on asset }(\text { ROA })=\frac{\text { Laba Bersih setelah pajak }}{\text { Rata-rata Total aset }} \times 100 \%
$$

Tahap akhir audit laporan keuangan adalah tahap pelaporan audit. Pada tahap ini seorang auditor akan memberikan pendapatnya atas laporan keuangan yang telah diauditnya. Auditor menyatakan pendapatnya berpijak pada audit yang dilaksanakan berdasarkan standar auditing dan atas temuan-temuannya. Penelitian ini menggunakan dua klasifikasi pendapat auditor yang dihitung secara dummy, yaitu wajar tanpa pengecualian (unqualified opinion) diberi nilai dummy 1 dan opini selain wajar tanpa pengecualian diberi dummy 0 , seperti yang digunakan Ashton, dkk (1987).

Solvabilitas merupakan kemampuan perusahaan dalam melunasi semua kewajiban-kewajibannya baik yang bersifat jangka pendek maupun jangka panjangnya (Kartika, 2011). Dalam penelitian ini pengukuran tingkat solvabilitas diukur dengan menggunakan rasio debt equity ratio (DER). Rasio DER biasanya diukur dengan total hutang dibagi dengan total ekuitas, tetapi dalam penelitian ini telah sedikit dimodifikasi yaitu rata-rata total hutangnya dibagi dengan dengan rata-rata total ekuitas., tetapi telah sedikit dimodifikasi yaitu rata-rata total hutangnya dibagi dengan dengan rata-rata total ekuitas. Karena tidak relevan jika 
hanya memakai awal tahun dan akhir tahun sebab salah satu komponen dari ekuitas adalah laba yang berubah-rubah setiap bulannya.

$$
\text { Debt Equity Ratio }(D E R)=\frac{\text { rata }- \text { rata total hutang }}{\text { rata }- \text { rata total ekuitas }} \times 100 \%
$$

Jenis data kuantitatif digunakan dalam penelitian ini. Data kuantitatif dalam penelitian ini diperoleh melalui laporan keuangan yang disajikan oleh perusahaan manufaktur yang terdaftar di Bursa Efek Indonesia tahun 2013-2015. Data sekunder dalam penelitian ini adalah laporan keuangan yang diperoleh dari perusahaan manufaktur yang terdaftar di Bursa Efek Indonesia (BEI). Data tersebut didapat dari situs resmi BEI yaitu www.idx.co.id selama tahun 20132015.

Populasinya merupakan seluruh sektor perusahaan manufaktur yang terdaftar di Bursa Efek Indonesia dalam periode waktu pengamatan selama 3 tahun dari 2013-2015 yang berjumlah 132 perusahaan. Jumlah sampel ditentukan dengan metode purposive sampling. Metode yang digunakan ini diharapkan mampu membuat sampel yang dipilih sesuai dengan kriteria pemilihan sampel yang telah ditentukan. Adapun kriteria yang digunakan untuk seleksi sampel dapat dilihat pada Tabel 1. berikut ini : 
Tabel 1.

Proses Seleksi Sampel dengan Purposive Sampling

\begin{tabular}{clc}
\hline No & \multicolumn{1}{c}{ Kriteria Penentuan Sampel } & Jumlah \\
\hline 1 & $\begin{array}{l}\text { Perusahaan manufaktur yang terdaftar di Bursa Efek Indonesia tahun } \\
\text { 2013-2015. }\end{array}$ & 132 \\
2 & Mempublikasikan laporan keuangan auditan periode 2013-2015. & 100 \\
& & \\
3 & Perusahaan memiliki periode akhir tahun buku per 31 Desember. & 80 \\
4 & Perusahaan menggunakan mata uang rupiah dalam laporan keuangan. & 55 \\
& Jumlah Sampel Terseleksi & 55 \\
& Tahun Pengamatan & 3 \\
& Total Jumlah Sampel Selama Periode Penelitian & 165 \\
\hline
\end{tabular}

Sumber: www.idx.co.id, 2017

Tabel 1 menunjukkan bahwa perusahaan manufaktur yang menjadi sampel dalam penelitian ini sebanyak 55 perusahaan per tahun pada periode 2013, 2014, dan 2015, sehingga didapatkan jumlah sampel (n) sebanyak 55 x $3=165$ sampel.

Metode pengumpulan data yang digunakan dalam penelitian ini yaitu metode observasi nonpartisipan. Observasi ini dilakukan dengan mengumpulkan data dengan cara mencatat, mengamati, mempelajari serta menganalisis data-data dalam bentuk laporan keuangan perusahaan sektor manufaktur yang telah terdaftar di Bursa Efek Indonesia selama tahun 2013-2015.

Teknik analisis data yang digunakan yaitu uji nilai selisih mutlak untuk menguji hipotesis. Alasan penggunaan uji nilai selisih mutlak adalah untuk mengurangi peluang terjadinya multikolinearitas pada model penelitian. (Frucot dan Shearon, 1991). Pengujian nilai selisih mutlak digunakan untuk mengetahui pengaruh profitabilitas terhadap audit delay serta untuk mengetahui kemampuan opini auditor memoderasi profitabilitas terhadap audit delay dan solvabilitas 
memoderasi pengaruh profitabilitas terhadap audit delay. Secara sistematis diperoleh persamaan regresi:

$$
\begin{aligned}
& \mathrm{Y}=\mathrm{a}+{ }_{\mathrm{b} 1} \mathrm{ZROA}+{ }_{\mathrm{b} 2} \mathrm{ZDER}+{ }_{\mathrm{b} 3} \mathrm{ZOP}+{ }_{\mathrm{b} 4}|\mathrm{ZROA}-\mathrm{ZDER}|+ \\
& { }_{\mathrm{b} 5}|\mathrm{ZROA}-\mathrm{ZOP}|+
\end{aligned}
$$

$\begin{array}{lll}\text { Keterangan } & : & \\ \text { Y } & : & \text { Audit delay } \\ \text { ROA } & : & \text { Profitabilitas } \\ \text { ZROA } & : & \text { Nilai standardized score Profitabilitas } \\ \text { ZDER } & : & \text { Nilai standardized score Solvabilitas } \\ \text { ZOP } & : & \text { Nilai standardized score Opini Audit } \\ \alpha & : & \text { Konstanta } \\ \beta 1-\beta 5 & : & \text { Koefisien Regresi } \\ \mid \text { ZROA-ZDER| } & : & \begin{array}{l}\text { Interaksi Profitabilitas dengan Solvabilitas yang diukur } \\ \text { dengan nilai absolut perbedaan antara ZROA dan ZDER }\end{array} \\ \mid \text { ZROA - ZOP| } & : & \begin{array}{l}\text { Interaksi profitabilitas dengan Opini Audit yang diukur } \\ \text { dengan nilai absolut perbedaan antara ZROA dan ZOP }\end{array} \\ \text { e } & : & \text { error } \text { atau variabel pengganggu }\end{array}$

\section{HASIL DAN PEMBAHASAN}

Analisis statistik deskriptif digunakan untuk menggambarkan karakteristik sampel berupa nilai tertinggi, nilai terendah, standar deviasi, dan nilai rata-rata. Tabel 2 memperlihatkan hasil uji statistik deskriptif sebagai berikut.

Tabel 2.

Hasil Statistik Deskriptif

\begin{tabular}{lc|c|c|c|c}
\hline & $\mathbf{N}$ & Minimum & Maximum & Mean & Std. Deviation \\
\hline ROA & 165 & -14.63 & 25.34 & 4.7104 & 7.13582 \\
DER & 165 & -3.54 & 7.76 & 1.3272 & 1.57932 \\
OP & 165 & .00 & 1.00 & .8909 & .31270 \\
AD & 165 & 34.00 & 102.00 & 75.7576 & 13.31840 \\
\hline
\end{tabular}

Sumber: Data diolah, 2017

Berdasarkan tabel 2. dapat disimpulkan bahwa jumlah pengamatan $(\mathrm{N})$ pada penelitian ini adalah sebanyak 165. 
Hasil perhitungan analisis deskriptif dari variabel profitabilitas $\left(\mathrm{X}_{1}\right)$ memiliki nilai minimum sebesar $-14,63$ dan nilai maksimum sebesar 25,34. Secara keseluruhan variabel profitabilitas memiliki nilai rata-rata sebesar 4,7104 mendekati nilai minimum artinya rata-rata perusahaan memiliki profitabilitas yang tergolong rendah, dengan standar deviasi sebesar 7,1358 nilai ini lebih tinggi dibandingkan dengan nilai rata-rata. Hal ini menunjukkan bahwa ada indikasi sebaran data profitabilitas tidak merata.

Hasil perhitungan analisis deskriptif dari variabel opini auditor $\left(\mathrm{X}_{2}\right)$ memiliki nilai minimum sebesar 0,00 yang berarti pendapat yang diberikan selain wajar tanpa pengecualian dan nilai maksimum sebesar 1,00 yang berrarti opini yang diberikan wajar tanpa pengecualian dengan nilai rata-rata sebesar 0,8909 yang artinya sebagian besar dari perusahaan memiliki opini wajar tanpa pengecualian karena nilai rata-rata mendekat 1 . Standar devisiasi pada variabel opini auditor adalah sebesar 0,31270.

Hasil perhitungan analisis deskriptif dari variabel solvabilitas $\left(\mathrm{X}_{3}\right)$ memiliki nilai minimum sebesar $-3,54$ dan nilai maksimum sebesar 7,76. Secara keseluruhan variabel solvabilitas memiliki nilai rata-rata sebesar 1,3272 mendekati nilai minimum artinya rata-rata perusahaan memiliki solvabilitas yang tergolong rendah, dengan standar deviasi sebesar 1,5793 nilai ini lebih tinggi dibandingkan dengan nilai rata-rata. Hal ini menunjukkan bahwa ada indikasi sebaran data solvabilitas tidak merata.

Hasil perhitungan analisis deskriptif dari variabel audit delay (Y) memiliki nilai minimum sebesar 34,00 dan nilai maksimum sebesar 102,00. Secara 
keseluruhan variabel audit delay memiliki nilai rata-rata sebesar 75,7576 mendekati nilai maksimum artinya rata-rata perusahaan memiliki audit delay yang tergolong tinggi, dengan standar deviasi sebesar 13,3184 nilai ini lebih rendah dibandingkan dengan nilai rata-rata. Hal ini menunjukkan bahwa sebaran data audit delay sudah merata.

Uji normalitas bertujuan untuk menguji apakah dalam sebuah model regresi variabel terikat dan variabel bebas keduanya mempunyai distribusi normal atau tidak. Model regresi yang baik adalah memiliki distribusi normal atau mendekati normal. Uji normalitas menggunakan uji statistik Kolmogorov-Smirnov Test Residual, model regresi berdistribusi normal jika memiliki nilai signifikansi >0,05.

Tabel 3.

Hasil Uji Normalitas

\begin{tabular}{lr}
\hline Test Statistic & 0,067 \\
Asymp. Sig. (2-tailed) & 0,070 \\
\hline Sumber: Data diolah, 2017 &
\end{tabular}

Berdasarkan Tabel 3 diketahui nilai signifikansi Asymp. Sig. (2-tailed) dari model penelitian yang digunakan lebih besar dari taraf signifikansi $>0,05$. Hasil tersebut memiliki arti bahwa model yang digunakan dalam penelitian ini berdistribusi normal.

Uji multikolinearitas bertujuan untuk menguji apakah model regresi ditemukan adanya korelasi antar variabel bebas. Pengambilan keputusan pada uji multikolinearitas dapat diketahui dengan cara melihat nilai tolerance dan nilai VIF masing-masing variabel independen, jika nilai tolerance $\leq 0,10$ dan nilai VIF $\leq 10$, maka dapat disimpulkan data bebas dari gejala multikolinieritas. Hasil uji multikolinearitas disajikan pada tabel 4.4. 
Tabel 4.

Hasil Uji Multikolinearitas

\begin{tabular}{|c|c|c|}
\hline Variabel & Tolerance & VIF \\
\hline ROA & 0,845 & 1,183 \\
\hline DER & 0,828 & 1,208 \\
\hline OP & 0,974 & 1,026 \\
\hline
\end{tabular}

Sumber: Data diolah, 2017

Berdasarkan tabel 4. dapat dilihat bahwa nilai tolerance masing-masing variabel adalah $>0,10$ dan nilai $\mathrm{VIF}<10$, sehingga dapat disimpulkan bahwa masing-masing variabel bebas pada model penelitian tidak mengalami gejala multikolinearitas.

Uji heteroskedastisitas bertujuan untuk menguji apakah dalam model regresi terjadi ketidaksamaan variance dan residual satu pengamatan ke pengamatan yang lain. Model regresi yang baik adalah yang homoskedastisitas atau tidak terjadi heteroskedastisitas. Salah satu cara untuk mendeteksi ada atau tidaknya heteroskedastisitas digunakan metode glejser. Hasil uji heteroskedastisitas disajikan pada Tabel 5 .

Tabel 5. Hasil Uji Heteroskedastisitas

\begin{tabular}{llc}
\hline & Variabel & Sig. \\
\hline 1 & ROA & 0,067 \\
2 & DER & 0,634 \\
3 & OP & 0,987 \\
\hline
\end{tabular}

Sumber: Data diolah, 2017

Berdasarkan Tabel 5. dapat dilihat bahwa variabel bebas tidak berpengaruh signifikan pada absolute residual dari model yang digunakan karena signifikansi setiap variabel bebas lebih besar dari taraf nyata $(\alpha)$ yaitu 0,05. Sehingga dapat disimpulkan bahwa tidak terjadi heteroskedastisitas. 
Suatu model regresi jika mengandung gejala autokorelasi, maka prediksi yang dilakukan dengan model tersebut akan tidak baik, atau dapat memberikan hasil prediksi yang menyimpang. Mendeteksi autokorelasi dengan menggunakan nilai Durbin Waston dibandingkan dengan tabel durbin waston (dl dan du) kriteria jika du $<$ d hitung $<4$-du maka tidak terjadi autokorelasi. Hasilnya tampak pada tabel berikut:

Tabel 6.

Hasil Uji Autokorelasi

\begin{tabular}{cc}
\hline Model & Durbin-Watson \\
\hline 1 & 1,818 \\
\hline Sumber: Data diolah, 2017 &
\end{tabular}

Pada tabel durbin waston diperoleh nilai dU untuk model penelitian $=1,732$ dan $\mathrm{dL}=1,603$. Maka nilai autokorelasi diantara $1,732<1,818<2,268(4-\mathrm{dU})$ sehingga tidak terjadi autokorelasi.

Analisis yang digunakan dalam penelitian ini adalah uji nilai selisih mutlak untuk menguji pengaruh profitabilitas terhadap audit delay serta kemampuan variable opini audit $\left(\mathrm{X}_{2}\right)$ dan solvabilitas $\left(\mathrm{X}_{3}\right)$ dalam memoderasi hubungan antara profitabilitas $\left(\mathrm{X}_{1}\right)$ terhadap audit delay $(\mathrm{Y})$. Hasil yang diperoleh hasil uji nilai selisih mutlak dapat dilihat pada Tabel 7. 
Tabel 7.

Hasil Uji Nilai Selisih Mutlak

\begin{tabular}{|c|c|c|c|c|c|c|}
\hline \multirow{2}{*}{\multicolumn{2}{|c|}{ Model }} & \multicolumn{2}{|c|}{ Unstandardized Coefficients } & \multirow{2}{*}{$\begin{array}{c}\text { Standardized } \\
\text { Coefficients } \\
\text { Beta }\end{array}$} & \multirow[b]{2}{*}{$\mathbf{t}$} & \multirow[b]{2}{*}{ Sig. } \\
\hline & & B & Std. Error & & & \\
\hline \multirow[t]{8}{*}{1} & (Constant) & 77,660 & 2,100 & & 36,972 &, 000 \\
\hline & Zscore(ROA) & $-5,776$ & 1,141 &,- 434 & $-5,062$ & 000 \\
\hline & Zscore(DER) & $-3,521$ & 1,243 &,- 264 & $-2,833$ & ,005 \\
\hline & Zscore(OP) & $-4,937$ & 1,495 &,- 371 & $-3,302$ & 001 \\
\hline & MDER & 3,547 & 1,178 & 297 & 3,012 & 003 \\
\hline & MOP & $-5,590$ & 1,857 &,- 363 & $-3,011$ & ,003 \\
\hline & Adjusted $R S q$ & $=0,150$ & & & & \\
\hline & Sig. F & $=0,000$ & & & & \\
\hline
\end{tabular}

Berdasarkan Tabel 7 di atas, maka dapat disusun persamaan regresi sebagai berikut :

$$
\begin{aligned}
& Y=a+b 1 Z R O A+b 2 Z D E R+b 3 Z O P+b 4|Z R O A-Z D E R|+ \\
& \text { b5 }|Z R O A-Z O P|+\text { e. } \\
& =77,660-5,776-3,521-4,937+3,547-5,590+e
\end{aligned}
$$

Keterangan :

$\begin{array}{lll}\text { Y } & : & \text { Audit Delay } \\ \text { ROA } & : & \text { Profitabilitas } \\ \text { ZROA } & : & \text { Nilai standardized score Profitabilitas } \\ \text { ZDER } & : & \text { Nilai standardized score Solvabilitas } \\ \text { ZOP } & : & \text { Nilai standardized score Opini Audit } \\ \alpha & : & \text { Konstanta } \\ \beta 1-\beta 5 & : & \text { Koefisien Regresi } \\ \mid \text { ZROA-ZDER| } & : & \begin{array}{l}\text { Interaksi Profitabilitas dengan Solvabilitas yang diukur } \\ \text { dengan nilai absolut perbedaan antara ZROA dan ZDER }\end{array} \\ \mid \text { ZROA - ZOP| } & : & \begin{array}{l}\text { Interaksi profitabilitas dengan Opini Audit yang diukur } \\ \text { dengan nilai absolut perbedaan antara ZROA dan ZOP } \\ \text { error atau variabel pengganggu }\end{array} \\ \text { e } & : & \end{array}$

Hasil uji nilai selisih mutlak model pada Tabel 4.7 menunjukan bahwa nilai Adjusted $\mathrm{R}^{2}$ sebesar 0,150 . Hal ini berarti 15 persen variabel audit delay mampu dijelaskan oleh variabel profitabilitas, opini audit dan solvabilitas sedangkan 
sisanya sebesar 85 persen dijelaskan oleh faktor-faktor lain yang tidak dijelaskan di dalam model.

Uji $\mathrm{F}$ digunakan untuk menguji apakah variabel bebas memiliki pengaruh terhadap variabel terikat. Berdasarkan hasil pengolahan data dengan program Statistical Package for the Social Science (SPSS) versi 24 ditemukan hasil pada model penelitian nilai signifikansi $\mathrm{F}=0,000<$ alph $a=0,05$. Hal ini berarti model yang digunakan pada penelitian ini adalah layak (fit). Berdasarkan hasil tersebut, dapat disimpulkan bahwa seluruh model dalam penelitian ini adalah layak (fit).

Hasil uji hipotesis pertama yang disajikan pada Tabel 7 menunjukkan bahwa nilai koefisien beta $\left(b_{1}\right)$ adalah $-5,776$ dengan angka probabilitas dan signifikansi sebesar $0,000<0,05 ;$ maka $\mathrm{H}_{1}$ diterima, ini berarti semakin rendah tingkat profitabilitas perusahaan maka audit delay semakin lama ataupun sebaliknya audit delay akan lebih singkat terjadi pada perusahaan yang mengalami profitabilitas tinggi. Koefisien regresi bernilai -5,776 menunjukan bahwa profitabilitas berpengaruh negatif pada audit delay. Hasil penelitian ini juga didukung oleh penelitian Liestya Oktarini (2013), Yogi (2014), Ovan dan Dwiana (2016) dan Miradhi (2016).

Perusahaan dengan profitabilitas tinggi akan berharap auditor melaksanakan audit dengan tepat waktu, sehingga laporan keungan dapat diumumkan kepada publik secepatnya (Sagita, 2011). Tujuanya adalah untuk menunjukan kinerja yang baik serta selalu melaporkan kondisi terkini perusahaan sesuai dengan peraturan yang diberlakukan oleh otoritas jasa keuangan (OJK) selaku otoritas pasar modal 
(Rahmayanti, 2016). Dengan demikian, audit delay akan lebih singkat pada perusahaan yang memiliki profitabilitas tinggi (Iskandar dan Trisnawati, 2010).

Hasil uji hipotesis kedua yang disajikan pada Tabel 7 menunjukkan bahwa nilai koefisien beta $\left(b_{5}\right)$ adalah $-5,590$ dengan angka probabilitas dan signifikansi sebesar $0,003<0,05$; maka $\mathrm{H}_{2}$ diterima, yang berarti terdapat moderasi opini audit dan memperkuat pengaruh negatif profitabilitas terhadap audit delay, dimana hal ini menunjukkan bahwa perusahaan yang mendapatkan opini wajar tanpa pengecualian akan mempersingkat adanya audit delay karena itu merupakan good news bagi perusahaan tersebut dan juga sebaliknya bila perusahaan mendapat opini audit selain wajar tanpa pengecualian mungkin terjadi adanya negosiasi yang akan dilakukan oleh pihak manajemen perusahaan dengan auditor karena itu merupakan bad news bagi perusahaan yang akan menyebabkan audit delay menjadi lebih lama.

Hasil uji hipotesis ketiga yang disajikan pada Tabel 7 menunjukkan bahwa nilai koefisien beta $\left(b_{4}\right)$ adalah 3,547 dengan angka probabilitas dan signifikansi sebesar $0,003<0,05 ;$ maka $\mathrm{H}_{3}$ diterima yang berarti terdapat moderasi solvabilitas dan memperlemah pengaruh negatif profitabilitas terhadap audit delay, dimana hal ini menunjukkan bahwa solvabilitas yang tinggi akan meningkatkan audit delay, karena apabila perusahaan yang memiliki tingkat solvabilitas yang tinggi akan memerlukan sumber dana yang tinggi pula sehingga akan mengurangi profit perusahaan dan akan memakan waktu untuk mengecek semua hutang dan kewajiban yang harus dibayar perusahaan sehingga audit delay akan lebih lama. 
Ketika proporsi hutang terhadap jumlah ekuitas meningkat, maka mengaudit akun hutang akan memakan waktu relatif lebih lama karena harus mencari sumber penyebab dari tingginya proporsi hutang yang dimiliki oleh perusahaan serta membutuhkan banyak waktu dalam mengkonfirmasi pihak-pihak yang berkaitan dengan hutang perusahaan (Aryaningsih, 2104). Saat setelah laporan keuangan disajikan dan perusahaan tersebut mempunyai solvabilitas tinggi hal ini merupakan bad news dalam laporan keuangan. Tingkat solvabilitas yang tinggi dalam laporan keungan mencerminkan adanya financial distress.Hal ini akan memicu terjadinya audit delay.

\section{SIMPULAN}

Berdasarkan hasil analisis data dan pembahasan yang telah diuraikan diatas maka dapat ditarik kesimpulan bahwa profitabilitas berpengaruh negatif terhadap audit delay, opini audit berpengaruh negatif dalam memoderasi dan memperkuat pengaruh negatif profitabilitas terhadap audit delay, dan solvabilitas berpengaruh positif dalam memoderasi dan memperlemah pengaruh negatif profitabilitas terhadap audit delay.

Saran-saran yang dapat diberikan terkait dengan hasil penelitian serta untuk kesempurnaan penelitian selanjutnya yaitu perusahaan emiten hendaknya menghasilkan profitabilitas yang baik karena dengan profitabilitas yang baik audit delay akan semakin singkat dan juga dengan adanya profitabilitas yang baik merupakan good news bagi perusahaan tersebut, sehingga peluang untuk mendapatkan opini wajar tanpa pengecualian dari auditor semakin besar. Pada penelitian selanjutnya diharapkan menambahkan variabel lain yang dapat 
I Gede Ari Dewanto dan A.A Ngurah Bagus Dwirandra. Opini...

mempengaruhi audit delay karena nilai koefisien determinasi variabel profitabilitas,opini audit dan solvabilitas mampu menjelaskan audit delay dalam penelitian ini hanya sebesar $15 \%$ sedangkan sisanya $85 \%$ dijelaskan oleh faktor lain diluar model.

\section{REFERENSI}

Abdulla, J. Y A. (1996). The Timeliness of Bahraini annual reports. Advances in International Accounting, 9, 73-88.

Anindyanari, N. W. C. P. (2017). Faktor-faktor yang mempengaruhi audit delay. Skripsi. Universitas Udayana

Arens, A. A., R. J. Elder., M. S. Beasley dan A. A. Yusuf. (2012). Jasa audit dan Assurance. Jakarta: Salemba Empat.

Aryaningsih, D dan I. K. Budiartha. (2014). Pengaruh Total Aset, Tingkat Solvabilitas Dan Opini Audit Pada Audit Delay. E-Jurnal Akuntansi Universitas Udayana, 7(3), 747-647.

Ashton, R. H., J. J. Willingham, and R. K. Elliott. (1987). Audit Delay and the Timeliness of Corporate Reporting. Contemporary Accounting Reserch, 657-673.

Astika, P. (2010). Teori Akuntansi :Konsep-konsep Dasar Akuntansi. Denpasar: Udayana University Press.

Bapepam-LK. (2011). Surat Keputusan Ketua Bapepam Nomer: Kep346/BL/2011. Penyampaian Laporan Keuangan Tahunan Emiten atau Perusahan Publik.

Carslaw, C.A.P.N. dan S.E. Kaplan. (1991). An Examination of Audit Delay: Further Evidence from New Zealand. Accounting and Business Research, 22(85), 21-32.

Dania, M. K., dan I. K. Sujana. (2017). Pengaruh Opini Audit, Audit Tenure, Komisaris Independen, dan Kepemilikan Manajerial Pada Ketepatwaktuan Publikasi Laporan Keuangan. Jurnal Akuntansi. 20(1),729-757.

Darmayanti, R. E. (2014). Pengaruh Kualitas Audit, Ukuran Perusahaan dan Opini Auditor terhadap Lamanya Audit Delay pada Perusahaan yang Terdaftar di BEI. Skripsi. STIE MDP Palembang.

Destina, A. (2010). Determinan ROA, Der, Size, Opini Audit, dan Kualitas Auditor terhadap Audit Delay yang terdaftar di Bursa Efek Indonesia Tahun 2008-2010. Skripsi. Universitas Dian Nuswantoro-Semarang. 
Dyer, J. D. and A. J. McHough. (1975). The Timeliness of The Australian Annual Report. Journal of Accounting Research Autumn, 204-219.

Estrini, D. H. dan L. Herry. (2013). Analisis Faktor-Faktor Yang Mempengaruhi Audit Delay. Diponegoro Journal Of Accounting, 2(2).

Ferdianto, R. (2011). Pengaruh Ukuran Perusahaan, Profitabilitas, Solvabilitas, Opini Auditor dan Reputasi Kap terhadap Audit Delay pada Perusahaan Sektor Barang Konsumsi yang terdaftar Di Bursa Efek Indonesia. Skripsi. Universitas Gunadarma

Fruscot, V. dan. S. Winston. (1991). Budgetary Parcipation, Locus of Control, and Mexican Managerial Performance and Job Satisfaction. The Accounting Review, 66(1), 80-99.

Givoly, D. and Palmon, D. (1982). Timeliness of Annual Earning Announcements: Some Empirical Evidence. The Accounting Review, 7(3).

Govindarajan, Vijay. (1986). Impact of Participation in The Budgetary Process on Managerial Attitudes and Performance: Universalitic and Contingency

Hajiha and Rafiee. (2011). The Impact of Internal Audit Function Quality on Audit Delays. Middle-East Journal of Scientific Research, 10(3), 389-397.

Halim, Abdul. (2008). Auditing (Dasar-dasar Audit Laporan Keuangan). UUP STM

Ikbal, M., N. Harsa., dan B. Usman. (2012). Pengaruh Audit Delay, Size, Profitability, dan Age terhadap Ketepatan Waktu Pelaporan Keuangan pada Perusahaan Manufaktur di Bursa Efek Indonesia. Management Insight, 8(1), 67-80.

Iskandar, M. J. dan E. Trisnawati. (2010). Faktor-faktor yang Mempengaruhi Audit Report Lag pada Perusahaan yang terdaftar di Bursa Efek Indonesia. Jurnal Bisnis dan Akuntansi, 12(3), 175-186.

Jaggi, B., dan J. Tsui. (1999). Determinants of audit report lag: Further evidence from Hong Kong. Accounting and Business Research, 30(1), 17-28.

Jama'an. (2008). Pengaruh Mekanisme Corporate Governance, dan Kualitas Kantor Akuntan Publik terhadap Intergritas Informasi Laporan Keuangan (Studi Kasus Perusahaan Publik yang Listing di BEJ). Tesis. Universitas Diponegoro. Semarang.

Jensen, M. C. dan W. H. Meckling. (1976). "Theory of the Firm: Managerial Behaviour, Agency Costs and Ownership Structure". Journal of Financial Economic, 3(4), 305-360

Karang, D. U. (2015). Pengaruh Faktor Internal dan Eksternal pada Audit Delay (Studi Empiris pada Perusahaan-perusahaan yang Terdaftar di Bursa Efek Indonesia). Tesis. Universitas Udayana 
Kartika, A. (2011). Faktor-faktor yang Mempengaruhi Audit Delay pada Perusahaan Manufaktur yang Terdaftra di BEI. Dinamika Keuangan dan Perbangkan, 3(2).

Lestari, D. (2010). Analisis Faktor-Faktor Yang Mempengaruhi Audit Delay: Studi Empiris Pada Perusahaan Consumer Goods Yang Terdaftar di Bursa Efek Indonesia. Skripsi. Universitas Diponegoro.

Liestya, N. M. O. (2013). Analisis Faktor-faktor yang Mempengaruhi Ketidaktepatwaktuan Pelaporan Keuangan pada Perusahaan yang terdaftar di Bursa Efek Indonesia Tahun 2012. Skripsi. Universitas Udayana.

Mantik, S. dan Sujana, E. (2012). Analisis Faktor yang Mempengaruhi Audit Delay pada Perusahaan Food and Beverages Tercatat di BEI 2009-2011. Skripsi. Univesitas Pendidikan Ganesha.

Miradhi, M. D., dan G. Juliarsa. (2016). Ukuran Perusahaan Sebagai Pemoderasi pengaruh Profitabilitas dan Opini Auditor pada Audit Delay. Skripsi. Universitas Udayana.

Mulyadi. (2009). Akuntansi Biaya. Yogyakarta: STIE YPKPN.

Ovan, P. G. S., dan I. M. D. Putra. (2016). Ukuran Perusahaan Sebagai Pemoderasi Pengaruh Opini Auditor, Profitabilitas, dan Debt Equty Ratio terhadap Audit Delay. Skripsi. Universitas Udayana

Owusu, S., \& Ansah. (2000). "Timeliness of Corporate Financial Reporting in Emerging Capital Market : Empirical Evidence From The Zimbabwe Stock Exchange". Journal Accounting and Business, 30. 241.

Parameswari, T. (2012). Analisis Faktor - Faktor Yang Mempengaruhi Terjadinya Audit Delay pada Perusahaan Consumer Good Industry Di Bursa Efek Indonesia (Periode Tahun 2008-2010). Akurat Jurnal Ilmiah Akuntansi,1930 .

Prosongkoputra, A. (2013). Faktor-faktor yang mempengaruhi Audit Delay. Skripsi. Universitas Islam Negeri Syarif Hidayatullah Jakarta.

Purnamasari, C. P. (2012). Analisis Faktor-faktor yang Mempengaruhi Terjadinya Audit Delay pada Perusahaan LQ 45 yang Terdaftar di Bursa Efek Indonesia. Skripsi. Universitas Gunadarma

Puspitasari, Elen. (2012). Pengaruh Karakteristik Perusahaan terhadap Lamaya Waktu Penyelesaian Audit (Audit Delay) pada Perusahaan Manufaktur yag Terdaftar di Bursa Efek Indonesia. Jurnal akuntansi dan Auditing, 9(1), 1-96.

Rachmawati, Sistya. (2008). Pengaruh Faktor Internal dan Eksternal Perusahaan Terhadap Audit Delay dan Timeliness. Jurnal Akuntansi Dan Keuangan, 10(1), 1-10. 
Rahmayanti, Dewi. (2016). Audit Dealy, Profitability, dan Konstribusi terhadap Ketepatan Waktu. Advance, 3(1).

Setiawan, Heru. (2013). Pengaruh Ukuran Perusahaan, Reputasi Auditor, Opini Audit, Profitabilitas,Dan Solvabilitas Terhadap Audit Delay. Skripsi. Universitas Islam Negeri Syarif Hidayatullah

Subalno. (2009). Analisis Pengaruh Faktor Fundamental dan Kondisi Ekonomi Terhadap Return Saham (Studi Kasus Pada Perusahaan Otomotif dan Komponen yang Listed di BEI Periode 2003-2007). Orbith, 6(1), 1-8.

Yogi, I. B. M. (2014). Pengaruh Komisaris Independen, Kepemilikan Institusional, Profitabilitas, Likuiditas, dan UKuran Perusahaan Terhadap Ketepatwaktuan Publikasi Laporan Keungan Tahunan (Studi Pada Perusahaan Perbankan ang Terdaftar di Bursa Efek Indonesia Tahun 20092012) Skripsi. Universitas Udayana 